\title{
ANALISA KEBIJAKAN SKEMA KREDIT DAN PEMBIAYAAN USAHA TANI HUTAN
}

\author{
(An Analysis on Credit Scheme And Funding Policy of Smallholder \\ Private Forests)
}

\author{
Oleh / By : \\ Hariyatno Dwiprabowo
}

\begin{abstract}
Credit scheme aimed to small holders of private-forests or forest farming is a major effort to carry out greening (afforestation) to produce timber and or other forest products, and to conserve land by involving community participation. Ministry of Forestry launched Private Forest Credit Scheme (KUHR) starting in 1997 and had terminated the credit scheme in 1999 due to a potential failure. Nevertheles, in the future such credit scheme should get attention as one of options to support program for forestry sector development. This study is aimed to identify factors contributing to credit scheme failure, funding alternative, and recommend improvement for future credit scheme. Study synthesized various published and unpublished reports, primary and secondary data and information, and group discussion with stakeholders i.e. banks and company involved in partnership with farmers that had been involved in the past credit scheme. Results of study reveal several findings: (1) Credit schemes should be flexibly adapted to region socio-economic conditions; (ii) Farmers' partner should be selectively chosen to ensure credit repayment; (iii) Bank role in credit chenneling should be adapted to the objective of the underlying program, and (iv) In the funding aspect, blend of funds of reforestation fund, national banks, and low rate oversea funding need to be sought.
\end{abstract}

Keywords : Credit scheme, forest farm, private forest smallholders

\begin{abstract}
ABSTRAK
Kredit usaha tani hutan merupakan suatu upaya untuk melaksanakan penghijauan pada lahan milik berupa kebun kayu dan atau aneka usaha kehutanan lain, disamping untuk tujuan konservasi melalui partisipasi masyarakat. Departemen Kehutanan menyelenggarakan Kredit Usaha Hutan Rakyat (KUHR) yang dimulai sejak tahun 1997. Kredit ini berakhir dengan dihentikannya pemberian kredit pada tahun 1999. Meskipun demikian dimasa mendatang kredit usaha bagi petani tetap perlu mendapat perhatian sebagai salah satu alternatif untuk mendukung program di sektor kehutanan. Tujuan dari kajian ini adalah untuk melihat faktorfaktor penyebab kegagalan kredit hutan rakyat, perbaikannya di masa mendatang, serta sumber pembiayaannya. Kajian bersifat sintesis dari berbagai sumber laporan, data primer dan sekunder, dan forum diskusi dengan pelaku kredit seperti bank dan mitra kelopok tani. Hasil kajian menunjukkan kredit usaha tani dimasa mendatang perlu memperhatikan, antara lain: (i) Pemberian paket kredit perlu disesuaikan dengan kondisi sosial ekonomi wilayah; (ii) Mitra kelompok tani perlu dipilih secara lebih selektif; (iii) Peranan bank dalam penyaluran kredit perlu dilihat secara lebih proporsional; (iv) Sumber pembiayaan selain berasal dari dana reboisasi, juga berasal dari perbankan nasional, dan sumber dana dari luar negeri.
\end{abstract}

Kata kunci: Skema kredit, usaha tani hutan, hutan rakyat 


\section{PENDAHULUAN}

Pada prinsipnya berbagai skema kredit usaha tani hutan memiliki tujuan yang sama yaitu memperluas basis partisipasi masyarakat dalam reboisasi dan penghijauan nasional atas dasar kemandirian usaha dengan bantuan kredit dari pemerintah. Dengan demikian peranan pemerintahan yang selama ini dominan didalam memperbaiki lingkungan sekaligus sebagai agen utama dalam produksi barang dan jasa kehutanan dapat semakin dikurangi.

Kredit usaha tani hutan (kayu) merupakan suatu upaya untuk melaksanakan penghijauan berupa kebun kayu dan aneka usaha kehutanan lain di tanah milik rakyat dengan bantuan kredit pinjaman kepada petani. Sebagai realisasi dari gagasan tersebut maka Departemen Kehutanan menyelenggarakan Kredit Usaha Hutan Rakyat (KUHR) dan Kredit Usaha Persuteraan Alam (KUPA), dan Kredit Usaha Konservasi Daerah Aliran Sungai (KUK DAS). Pengembangan hutan rakyat melalui program KUHR dimulai sejak tahun 1997 dan KUK DAS sejak tahun 1996 dengan sumber pendanaan dari Dana Reboisasi Departemen Kehutanan. Pengembangan hutan rakyat dilakukan untuk mengantisipasi terjadinya kelangkaan pasokan bahan baku industri yang selama ini berasal dari hutan alam. Disamping untuk menunjang kebutuhan bahan baku industri pengolahan kayu juga diharapkan dapat menangani lahan kritis yang ada di luar kawasan hutan, terutama lahan tidur milik masyarakat.

Keterbatasan modal bagi petani untuk mengusahakan lahannya telah mendorong pemerintah untuk menyediakan sarana permodalan berupa KUHR melalui pola kemitraan antara petani/kelompok tani dengan pengusaha (BUMN, BUMS dan Koperasi) sebagaimana tertuang dalam SK Menhutbun No.49/Kpts-II/1997.

Tujuan pemberian kredit hutan rakyat (SK Menhut: 101/kpts-V/1996) adalah :(1) Untuk meningkatkan kesejahteraan masyarakat, (2) Untuk meningkatkan mutu lingkungan dan (3) Menunjang pemenuhan bahan baku industri (hasil hutan).

Sasaran pelaksanaan KUHR adalah untuk mendanai kegiatan hutan rakyat yang dilaksanakan pada lahan hak milik di luar kawasan hutan dengan status pemanfaatan yang jelas dan lahan usaha II dari Transmigrasi yang direncanakan sebagai hutan rakyat (Trans HR). Sedangkan KUPA (SK Menhutbun No.50/Kpts-II/1997) adalah untuk mendanai kegiatan usaha tani persuteraan alam yang dilaksanakan pada lahan hak milik di luar kawasan hutan dengan status pemanfaatan yang jelas dan lahan usaha II dari Transmigrasi yang direncanakan usaha tani persuteraan alam.

Disamping kedua skema kredit ini terdapat skema kredit lain (KUKDAS) yang pada dasarnya memiliki tujuan yang sama namun diselenggarakan untuk meningkatkan kondisi lahan di DAS. Oleh karena itu KUK DAS diberikan untuk bangunan konservasi/fisik, pengadaan bibit tanaman pangan atau tanaman keras seperi karet dan kopi, pengadaan saprodi atau pengadaan ternak.

Dari aspek kelembagaan pelaku (stakeholders) dalam pelaksanaan kegiatan KUHR dan KUPA dari sisi fungsionil terdiri dari 4 fihak, yaitu : (1) petani dan kelompok tani, (2) mitra usaha, (3) pembina teknis di tingkat nasional, propinsi, kabupaten, dan kecamatan, dan (4) perbankan. Pelaku mempunyai keterkaitan dan sinergisme dalam mekanisme perkreditan baik dari pengajuan kredit, realisasi kredit, pelaksanaan kegiatan usaha, pembinaan teknis, dan pengawasan pelaksanaan kredit dan teknis silvikultur.

Pada umumnya kredit-kredit yang bertujuan untuk penghijauan seperti KUHR, KUKDAS, KUPA, berasal dari Dana Reboisasi yang pada awalnya diperuntukan untuk penghutanan kembali pada kawasan hutan. Namun dalam perkembangannya pemanfaatannya diperluas sehingga mencakup lahan di luar kawasan hutan. Dengan menurunnya produksi kayu bulat dari hutan alam maka penerimaan DR semakin menurun padahal luas kawasan hutan yang rusak sebagai akibat 
deforestasi semakin meningkat. Oleh karena itu perlu dilakukan penajaman prioritas maupun peningkatan efisiensi dalam penggunaan DR di masa mendatang. Upaya lainnya yang diperlukan adalah mencari sumber-sumber pandanaan lain yang tersedia bail di dalam dan luar negeri.

Tujuan kajian kebijakan ini adalah :

- Melakukan penilaian (assessment) atas kredit usaha tani hutan (KUHR);

- Mengkaji sumber pembiayaan kredit;

- Memberikan rekomendasi prekreditan usaha tani hutan.

\section{METODOLOGI}

Kajian dilakukan berdasarkan metode sintesis kualitatif dari (i) Laporan-laporan kredit usaha tani baik yang dipublikasikan atau tidak dipublikasikan, (ii) Data primer dan sekunder serta informasi lainnya dari lapangan. Data dan informasi diperoleh melalui wawancara dengan petani dan mitra petani, dan pencatatan dari instansi terkait. Di samping bahan-bahan tersebut bahan lain diperoleh dari forum diskusi yang khusus diadakan untuk membahas kredit usaha tani hutan yang melibatkan pihak bank, perusahaan mitra yang memiliki pengalaman bermitra dengan kelompok tani dalam Kredit Usaha Hutan Rakyat dan para peneliti.

\section{HASIL DAN PEMBAHASAN}

\section{A. Implementasi Kredit}

Hasil beberapa evaluasi (Sylviani, 2000; PT Forindo Bangun Konsultan, 1999) terhadap KUHR menunjukkan belum ada data pengembalian kredit di seluruh propinsi untuk hutan rakyat. Hal ini disebabkan KUHR yang mulai dilaksanakan tahun 1997 dan tempo jatuh kredit 10 tahun kemudian sehingga belum dimulai masa pengembalian kreditnya. Waktu jatuh tempo yang paling cepat berdasarkan jadwal pengembalian kredit adalah tahun 2006.

Evaluasi atas implementasi lapangan di Kabupaten Sukabumi menunjukkan beberapa faktor yang berpengaruh terhadap kegagalan kredit KUHR, yakni : (i) Penerima kredit adalah pengontrak lahan petani atau perantara, (ii) Petani memerlukan biaya yang cukup besar untuk mengurus sertifikat tanah, (3) Kondisi lapangan terutama pada lahan yang mememiliki kecuraman cukup besar memerlukan biaya tambahan untuk terasering, (iv) Beredarnya isyu bahwa kredit tidak perlu dikembalikan.

Evaluasi atas KUK DAS menunjukkan tingkat pengambalian yang bervariasi dengan ratarata $49.7 \%$ berupa pokok dan bunga, yang terendah terjadi di Kabupaten Musi Rawas dengan tingkat pengembalian kredit $23.2 \%$. Penyebab dari kegagalan tersebut dapat dikelompokkan kedalam aspek : (1) Pemasaran hasil, (2) Produksi, dan (3) Administrasi Kredit. Dari sisi pemasaran disebabkan : (i) pemilihan lokasi kurang tepat sehingga menyebabkan biaya transportasi yang tinggi , (ii) pilihan jenis tanaman kayu yang sulit dipasarkan. Dari aspek produksi disebabkan : (i) Tumpang tindih pemanfaatan lahan, dan (ii) kurang berhasilnya panen tanaman pangan dan ternak. Sedangkan dari sisi administrasi (ii) Proses penyaluran dana yang kurang lancar (Sylviani, 2002).

Kredit KUHR pada berbagai lokasi dihentikan penyalurannya mulai tahun 1999 pada berbagai tahap mulai tahap II, III, atau IV. Berdasarkan evaluasi atas data-data peluncuran keredit dan mitra penerima kredit, perusahaan yang menerima kredit terlama adalah PT XIP, Sumsel, dan 
PT BMP di Wonosobo,Jawa Tengah yakni hingga tahap V. Kedua perusahaan ini sama-sama memiliki industri pengolahan kayu dan memiliki pengalaman dalam bidang kehutanan.

Evaluasi atas KUHR yang telah dilaksanakan oleh Departemen Kehutanan yang berujung pada penghentian penyaluran KUHR pada berbagai wilayah tidak didasarkan atas kinerja pengembalian kredit mengingat kredit tersebut belum jatuh tempo. Keputusan penghentian tersebut lebih didasarkan pada prediksi kinerja pengembalian kredit berdasarkan indikator lapangan sebagaimana telah diuraikan di atas.

Secara umum efisiensi dan efektivitas penyaluran kredit Hutan Rakyat masih rendah hal ini disebabkan oleh : (i) ketidaksesuaian dalam pelaksanaan kredit antara yang tertulis dalam SK Menhutbun dengan perjanjian kredit dan penggunaannya, (ii) adanya kesenjangan waktu pencairan kredit yang disebabkan pemindahbukuan kredit yang seharusnya kepada petani diambil alih oleh pengusaha (mitra), (iii) perubahan biaya penggunaan saprodi akibat kenaikan harga, (iv) adanya kegiatan penggunaan kredit selain untuk tanaman pokok kehutanan (seperti ternak), (v) pencairan kredit yang lambat dan peningkatan biaya produksi berpengaruh terhadap jumlah kredit dan efisiensi penggunaannya ( Forindo Bangun Konsultan, 1999). Sedangkan efisiensi dan efektivitas penggunaan dan penyeluran kredit pada sutera alam secara umum lebih baik dibanding pada usaha hutan rakyat, yang ditunjukkan oleh : (i) adanya kesinergetikan antara SK Menhutbun dengan perjanjian kredit dan penggunaannya, (ii) semakin pendeknya kesenjangan waktu pencairan waktu kredit, tidak ada kegiatan yang menyalahi prosedur.

\section{B. Pola Paket Kredit}

Model model kredit dalam KUHR terbatas (kaku) kurang memperhatikan kebutuhan riel petani dan kondisi sosial budaya ekonomi masyarakat. Paket kredit yang diberikan untuk petani di $P$. Jawa dan Luar Jawa cenderung seragam. Padahal terdapat perbedaan dalam kondisi budaya dan luas pemilikan lahan pada kedua wilayah tersebut. Pada umumnya luas pemilikan lahan per keluarga di Luar Jawa (misal: Sumatera Selatan, Jambi) adalah antara 25 ha bahkan beberapa petani memiliki lahan dengan luas $>5$ ha. Di Jawa luas pemilikan lahan jauh lebih kecil, yakni, antara 0.25 ha 1 ha, sebagian besar berada pada kisaran 0.250 .50 ha. Kemampuan petani di Luar Jawa untuk mengolah lahan maksimum 1.5 ha/petani, pada umumnya lahan ini dipilih lahan yang paling subur untuk memenuhi kebutuhan hidup sehari-hari. Sedangkan sisanya adalah lahan tidur yang tidak terawat (berupa semak belukar). Tambahan modal seperti KUHR dimanfaatkan untuk membuka lahan tidur dengan berbagai jenis tanaman (kayu, kelapa sawit, dan karet). Sebaliknya di P. Jawa seluruh lahan digarap dan digunakan untuk memenuhi kebutuhan hidup, tanaman kayu ditanam pada ruang-ruang marginal yang masih tersisa.

Berdasarkan kondisi tersebut, hutan rakyat dengan penanaman kayu yang ekstensif lebih sesuai untuk luar P. Jawa, sedangkan di P. Jawa penanaman kayu dasarnya pohon per pohon. Oleh karena itu paket Aneka Usaha Kehutanan di P.Jawa dapat dikombinasikan dengan sejumlah pohon kayu-kayuan secara terbatas.

\section{Kelembagaan}

Kelembagaan KUHR (organisasi dan aturannya) bersifat gemuk. Pelaksanaan kegiatan KUHR dan KUPA dari sisi fungsional terdiri dari : (1) petani dan kelompok tani, (2) mitra usaha, (3) pembina teknis di tingkat nasional, propinsi, kabupaten dan kecamatan, dan (4) pihak perbankan. Mekanisme pelaksanaan kegiatan proyek dimulai dari tingkat pusat sampai propinsi dan kabupaten. Berdasarkan hasil evaluasi Forindo Bangun Konsultan (1999) secara umum keterkaitan antar keempat pelaku tersebut intensitas peranannya hanya pada saat persiapan proyek. Setelah melewati 
fase ini, mekanisme keterkaitan peran dan fungsi dari keempat pelaku relatif berkurang bahkan cenderung tidak jalan terutama dari aspek pembinaan dan pengawasan terhadap kegiatan penyaluran kredit. Keterlibatan banyak instansi dalam skema KUHR untuk keperluan pembinaan cenderung meningkatkan inefisiensi berupa pemborosan waktu dan dana. Dawson (1996) dikutip dalam Wahyudi dan Sulandari (2000) menggunakan dua indikator dalam evaluasi kinerja kelembagaan yakni efektivitas dan efisiensi. Efektivitas adalah kemampuan kelembagaan untuk mencapai tujuan yang telah ditetapkan. Dalam hal ini dilihat dari ketepatan waktu dan jumlah penyaluran dan pengembalian kredit. Sedangkan efisiensi merupakan rasio dari nilai input dengan nilai output. Suatu sistem kelembagaan dapat disebut efisien jika setiap elemen lembaga tersebut memebrikan kontribusi netto positif terhadap sistem. Secara operasional suatu sistem kelembagaan menjadi tidak efisien jika bertindak sebagai pencari rente belaka.

Hasil evaluasi terhadap pelaku memperlihatkan intensitas peranan stakeholders maksimal hanya pada saat persiapan proyek. Setelah fase ini, keterkaitan peran dan fungsi keempat pelaku berkurang dari aspek pembinaan dan pengawasan terhadap kegiatan penyaluran kredit (PT Forindo Bangun Konsultan, 1999).

Penggunaan bank channeling perlu dievaluasi kembali karena bank penyalur pada KUHR aturan-aturannya bersifat lokal/tidak seragam dari satu propinsi ke propinsi lainnya. Sebaliknya penggunaan bank nasional yang memiliki pengalaman perkreditan untuk usaha kecil lebih memberikan jaminan kelancaran operasional. Akhir-akhir ini muncul gagasan untuk membentuk "bank hijau" sebagai lembaga keuangan dalam sektor kehuatanan khusunya dalam pembangunan hutan mengingat kegiatan ini memiliki karakteristik yang khusus. Di samping itu peranan bank dapat ditingkatkan menjadi pelaksana sebagaimana penyaluran kredit lainnya sehingga memiliki tanggung jawab lebih besar atas operasi kredit maupun pengembaliannya.

Hal penting lainnya yang berakibat pada kegagalan KUHR adalah sasaran penerima kredit. Penerima kredit (mitra) sebagai pendamping petani ditetapkan badan hukum yang memiliki akses pasar. Kenyataan menunjukkan mitra yang memiliki akses pasar tidak berarti memiliki kemampuan untuk menjual hasil kayu dari petani dengan harga yang layak di pasar karena memiliki posisi tawar yang lemah dibandingkan industri kayu yang menerima. Ketidak jelasan mitra tersebut banyak menimbulkan penyalahgunaan kredit KUHR oleh pihak mitra. Hasil evaluasi atas data realisasi kredit KUHR dari Ditjen RRL (RLPS) menunjukkan bahwa dari seluruh kredit yang telah disalurkan pada berbagai propinsi hanya dua (2) mitra perusahaan saja yang memiliki kinerja baik, yakni, menerima kucuran kredit hingga tahap IV dan V, mitra lainnya dihentikan pada tahap II atau III. Kedua mitra perusahaan (berlokasi di Propinsi Sumatera Selatan dan Propinsi Jawa Tengah) tersebut adalah industri kayu yang hingga kini masih beroperasi dan selama ini menerima pasokan kayu dari hutan rakyat disamping itu memiliki pengalaman kehutanan (membangun hutan rakyat). Kontrak yang dilakukan perusahaan mitra dengan petani yang dilakukan sejak awal, perjanjian penjualan kayu dengan harga pasar, serta perjanjian pembagian keuntungan merupakan cara yang efektif bagi petani.

Peranan Dinas (propinsi dan kabupaten) maupun Intansi terkait lainnya, Kelompok Tani dalam Skema KUHR perlu ditinjau. Menurut Wahyudi dan Wulandari (2000) dalam kasus Sistem Perkreditan Usahatani Tebu, Kepala Desa, KUD, dan Dinas Perkebunan oleh sebagian besar petani dianggap sudah tidak diperlukan lagi. Evaluasi yang dilakukan terhadap perkreditan petani tebu menunjukkan bahwa kredit yang disalurkan kepada pabrik gula (PG) sebagai mitra petani tebu memiliki kinerja yang baik. Demikian pula PIR BUN kelapa sawit dengan bentuk kemitraan Perusahaan Perkebunan dengan petani kebun dengan pola plasma-inti memiliki tingkat pengembalian kredit yang tinggi $(75 \%)$. 
Skema kredit PIR BUN merupakan skema perkreditan yang berhasil dengan tingkat pengembalian hingga $75 \%$. Kunci keberhasilan ini antara lain disebabkan oleh: (i) Unit Manajemen Usaha yang jelas; (2) Komoditas yang dihasilkan yakni kelapa sawit memiliki keterkaitan pasar yang jelas yakni pabrik-pabrik pengolah CPO.

\section{Peranan Bank}

Peranan bank selama ini baik di bidang kehutanan (KUHR, KUPA) dan pertanian (PIR-BUN) adalah sebagai bank penyalur (channeling bank). Dalam KUHR bank bertindak sebagai penyalur pinjaman Dana Reboisasi (DR). Sebagai akibat tingginya sukubunga komersial serta jangka pinjaman yang umumnya bersifat jangka pendek, sedangkan usaha hutan tanaman bidang kehutanan berjangka waktu panjang dengan tingkat pengembalian yang relatif rendah membuat pendanaan dalam bidang kehutanan memerlukan pengaturan khusus. Menurut Hasan dari Bank Mandiri (2004) untuk mengatasi hal tersebut diperlukan pengaturan sebagai berikut:

Blended of Funds : Pemerintah menempatkan dana di perbankan dalam bentuk deposito abadi. Bunga deposito dan dana komersial perbankan dicampur dengan proporsi tertentu sehingga diperoleh sumber pendanaan jangka panjang dan berbunga rendah;

Resiko Kredit : Resiko yang muncul akibat pembiayaan ini ditanggung secara proporsional oleh pemerintah dan perbankan sesuai dengan share pembiayaannya;

Equity (self financing) : Nasabah berbentuk badan usaha wajib menyediakan self financing minimal $20 \%$ dari total pembiayaan hutan tanaman;

Jaminan kredit: Nasabah disyaratkan untuk menyerahkan jaminan tambahan.

Fasilitas kredit investasi diberikan kepada Kelompok Tani Hutan yang memiliki kerjasama kemitraan dengan industri kehutanan untuk pembangunan hutan tanaman dan atau rehabilitasi lahan kritis menjadi Hutan Rakyat. Kredit Hutan Rakyat diberikan hanya diberikan kepada Kelompok tani yang memiliki kerjasama dengan suatu industri kehutanan atau perusahaan perdagangan hasil hutan. Sedangkan pengelolaan fasilitas kredit dilakukan oleh Industri Kehutanan yang menjadi Mitra Usaha atas nama Kelompok Tani Hutan. berikut.

Ditinjau dari aspek perbankan, fungsi bank dalam perkreditan memiliki dua macam bentuk

\section{Fungsi penyaluran (Channeling)}

Dalam fungsi ini bank hanya menyalurkan kredit dengan komisi tertentu (komisi dalam penyaluran KUHR adalah sebesar $2 \%$ ). Bank secara operasional tidak melakukan fungsi pengawasan serta upaya paksa penarikan kredit, penyandang danalah yang melakukan kegiatankegiatan tersebut. Sebagian besar atau seluruh resiko kredit ditanggung oleh penyandang dana (pemerintah). Oleh sebab itu sebagai pemberi jaminan (avalis), pemerintah perlu menyimpan dana dalam jumlah yang memadai pada bank pelaksana untuk menanggung resiko kredit macet. Fungsi bank sebagai penyalur sangat sesuai untuk pelaksanaan program-program pemerintah yang tujuannya tidak semata-mata untuk tujuan komersial seperti KUHR pada waktu yang lalu.

\section{Fungsi pelaksanaan (Executing)}

Dalam fungsi ini, bank pelaksana memiliki tanggung jawab terhadap pengawasan serta pengembalian kredit, dan menanggung sebagian besar resiko atas kredit yang diberikan. Sebagai konsekuensinya sasaran (penerima) kredit perlu memenuhi persyaratan yang ditetapkan fihak bank berdasarkan analisa kredit yang berlaku. Pemerintah dapat menyertakan sebagian dana untuk 
menentukan besarnya kredit dan tingkat suku bunga yang diberikan. Fungsi bank sebagai pelaksana atau executing sesuai untuk program yang memiliki tujuannya dan sasaran ekonomi yang jelas serta secara finansial dapat dipertanggung jawabkan. Dalam kasus pembangunan hutan rakyat perlu lebih dipertegas unit manajamen usaha serta skala ekonominya serta komoditas yang akan dihasilkan dan ketersediaan pasarnya (keterkaitan dengan industri). Dalam konteks ini sudah selayaknya hutan rakyat dikembangkan menjadi sistem agribisnis.

Dalam melaksanakan program pemerintah yang bertujuan bukan semata-mata untuk tujuan ekonomi (komersial) seperti KUHR pada waktu yang lalu, bank cenderung mengambil posisi channeling untuk menghindarkan resiko (Munandar, 2004).

Menurut Hardjanto (2003) sistem usaha kayu rakyat terdiri empat sub sistem yaitu sub sistem produksi, sub sistem pengolahan, dan sub sistem pemasaran dan sub sistem kelembagaan. Keseluruhan sistem tersebut berpengaruh pada kinerja usaha kayu rakyat yang dirasakan belum optimal. Sistem agro-forest binis yang dikembangkan perlu memperhatikan keempat sub sistem agar bekerja secara optimal.

\section{E. Alternatif Skema Pembiayaan}

Pembiayaan untuk kehutanan sangat bervariasi tergantung pada siapa yang membiayai, untuk siapa dan apa yang dibiayai, dan berapa banyak dana yang terlibat. Terdapat mekanisme langsung dan tak langsung, secara individu dan lembaga, dan pinjaman atau hibah. Dari sisi sumber pembiayaan dapat diklasifikasikan kedalam domestik dan luar negeri, publik dan swasta. Terdapat pula kombinasi satu dengan lainnya maupun pembiayaan secara bersama satu sumber dengan lainnya.

\section{Pembiayaan dalam negeri}

Pemerintah selama ini memegang peranan dengan menerapkan berbagai instrumen untuk memobilisasi dana dari sektor kehutanan seperti royalti, iuran, dan pajak. Pembiayaan kredit hutan rakyat selama ini bersumber dari Dana Reboisasi dari Pemerintah (Departeman Kehutanan) dengan bunga nol persen pada bank pelaksana.

Menurut Repetto dan Sizer (1996) sektor kehutanan sebaiknya membiayai sendiri (self financing) dan barangkali tidak memerlukan sumber lain bagi investasi pengelolaan hutan yang berkelanjutan (INDUFOR, 1999). Jika kebijakan yang diterapkan tepat, dan rente yang potensial secara efektif dikumpulkan dan ditransfer kepada pengelola maupun pemilik hutan, tidak diperlukan sumber pembiayaan lain jika hutan dapat mencapai tingkat produktivitas minimum yang diperlukan. Dalam hal hutan yang dimiliki negara serta pengumpulan pajak dan iuran2 kehutanan, permasalahannya adalah pendapatan pemanfaatan hutan dikumpulkan oleh Menteri Keuangan, dan dana seringkali tidak secara khusus disisihkan untuk reinvestasi atau untuk memulihkan biaya pengelolaan sumber hutan dan konservasi.

Investasi domestik swasta dibatasi oleh tingkat ketersediaan dana baik dari sumber lokal maupun luar. Disamping dana dari industri skala besar maupun menengah, investasi swasta dilakukan oleh petani dan penduduk sekitar hutan, perusahaan skala kecil dimana semua memobilisasi dana dan sumber daya yang lain untuk pengelolaan hutan dan pengolahan hasil hutan.

Investasi oleh masyarakat pedesaan dan organisasinya tidak selalu tercatat dengan baik sehingga peranannya cenderung diabaikan oleh statistik resmi. Chandrasekharan (1996) menunjukkan pengalaman terakhir dalam pembangunan kehutanan menunjukkan apabila sumberdaya penduduk lokal dimobilisasi secara efektif, investasi kehutanan yang sangat produktif 
dan efektif akan terjadi pada biaya yang relatif rendah. Kebijakan yang kondusif untuk memberikan insentif yang terukur (tangible) dan dukungan yang terarah sangat penting untuk mencapai hal tersebut.

Pembiayaan dalam negeri selama ini sangat tergantung pada peranan sektor kehutanan dalam ekonomi nasional, dan prakondisi yang dapat membuat investasi pengelolaan hutan menguntungkan bagi sektor swasta.

\section{Official Development Assistance (ODA)}

\section{a. Sumber-sumber ODA}

Terdapat 2 (dua) mekanisme pembiayaan internasional konvensional utama yang telah diterapkan pada masa lalu untuk menyediakan dana bagi sektor kehutanan: official development assistance (ODA), dan investasi sektor swasta. Keduanya mengambil berbagai bentuk dan saluran (channel) dan seringkali saling terkait.

ODA khususnya memberikan support konservasi lingkungan, pembangunan sosial, infra struktur, capacity building, maupun menyediakan bimbingan teknisdan sumber daya lain sebagai katalisator pembangunan. Akhir-akhir ini telah berkembang keinginan untuk mensupport internalisasi eksternalitis global. Dalam kehutanan, isyu lingkungan dan sosial cenderung meningkat prioritasnya. Aliran ODA umumnya berbentuk hutang, hibah atau bantuan teknis. ODA memiliki 2 (dua) saluran utama:

(i) secara bilateral dari agen donor kepada penerima; atau

(ii) secara multilateral melalui badan-badan internasional yang memperoleh sumber dari badanbadan donor dan pasar keuangan internasional.

\section{b. Bank pembangunan multilateral}

Bantuan multilateral diberikan oleh bank pembangunan, badan-badan PBB dan organisasi khusus, dan NGO internasional. Diantara bank pembangunan multilateral (MDB), Bank Dunia selama ini merupakan pemberi dana terbesar dan kebijakannya cenderung diikuti oleh badan-badan lain. Kebijakan kehutanannya tahun 1992 telah meninggalkan pendanaan pembalakan hutan tropis primer. Dikarenakan konflik lokal maupun internasional yang berhubungan dengan penggunaan hutan, Bank Dunia dan bank pembangunan wilayah (AfDB, AsDB, dan IDB) telah mengalihkan focus-nya dari yang bersifat murni kehutanan kepada proyek-proyek terintegrasi dimana kehutanan merupakan bagian dari pembangunan pedesaan dan konservasi lingkungan. IFAD juga telah terlibat dalam pendanaan kegiatan-kegiatan kehutanan /penanaman pohon sebagai bagian dari proyekproyek pertanian.

\section{c. Badan internasional}

Bantuan teknis di bidang kehutanan disediakan oleh sejumlah badan-badan PBB seperti FAO, ITTO, ILO, ITC, UNDP, UNEP, UNESCO, UNIDO, WFP dan WHO. Global Environment Facility (GEF) dikelola oleh WB, UNDP dan UNEP sebagai instrumen untuk pembiayaan kehutanan. UNDP adalah saluran pendanaan utama dari PBB untuk pembangunan dan lingkungan melalui alokasi program pemerintah. Tahun 1993 UNDP sebagai tindak lanjut dari UNCED meluncurkan Forestry Capacity Program untuk membantu merumuskan dan mengimplementasikan program kehutanan nasional (NFP). Tahun 1998, UNDP meluncurkan Program on Forest (PROFOR) untuk mempromosikan SFM dan kemitraan sektor publik dan swasta yang terkait pada tingkat negara, 
untuk mensupport mata pencaharian yang lestari (sustainable livelihood).

ITTO memiliki focus pada promosi SFM di hutan-hutan tropis melalui intervensi dalam reforestasi dan pengelolaan hutan, industri kayu dan informasi ekonomi dan market intelligence. Badan ini membiayai proyek melalui Account khusus kemana kontribusi negara donor diberikan, termasuk sektor swasta. Akhir-akhir ini terdapat kecenderungan kejenuhan pendanaan ITTO dari negara donor.

\section{d. Lembaga bantuan non pemerintah}

Pembiayaan dari dana OPEC (Organisation for Petroleoum Exporting Countries) muncul akhir-akhir ini, bidang yang terbuka bagi pembiayaan adalah kehutanan dan pertanian. Untuk pembiayaan bidang kehutanan terdapat kegiatan timberland yakni pembelian dan reforestasi tegakan hutan (kayu). Disamping itu pembiayaan terbuka bagi kegiatan farm khususnya proyek peningkatan farm seperti irigasi dan penyiapan lahan, pembelian mesin dan peralatan, ternak, dan fasilitas ternak. Hutan rakyat memiliki peluang untuk dikembangkan pada kegiatan timberland atau farm.

Besarnya sukubunga pinjaman adalah sebagai berikut:

Besarnya pinjaman

US\$ 5 juta 50 juta US\$ 50 juta 100 juta US\$ 100 juta keatas

\section{Suku bunga}

LIBOR plus $2 \%-2 \frac{1}{4} \%$ (masih dapat dinegosiasi)

LIBOR plus $1 \%-1 \frac{1}{2} \%$

LIBOR plus $3 / 4 \%-1 \%$

Sumber : Opecfunds (2004)

Keterangan : LIBOR adalah singkatan dari London InterBank Offered Rates yakni tingkat suku bunga untuk pinjaman jangka pendek yang ditawarkan sekelompok bank di Inggris (London). Libor seringkali dijadikan rujukan tingkat sukubunga pinjaman antar bank. Sebagai contoh, tingkat LIBOR bulan September 2004 untuk jangka 1 tahun adalah $2.4445 \%$.

\section{e. Clean Development Mechanism}

Dengan ratifikasi Kyoto Protocol terbuka kemungkinan mendapatkan dana tambahan untuk program penghijauan/hutan rakyat melalui penjualan karbon melalui CDM (Carbon Development Mechanism). Berbagai perusahaan swasta di luar negeri khususnya yang bergerak dalam bidang pembangkitan energi memiliki kewajiban mengurangi emisi karbon yang ditimbulkannya. Meskipun nilai karbon relatif kecil dibandingkan dengan nilai kayunya, tambahan dana ini akan menjadi insentif tambahan dalam pembangunan hutan rakyat. Mekanisme jual beli karbon yang lebih operasional perlu diupayakan guna meningkatkan aksesibilitas perusahaan yang berminat. Dalam progam KUHR di masa mendatang, penghasilan dari penjualan karbon seyogyanya merupakan insentif tambahan bagi perusahaan mitra dan kelompok tani sehingga tidak menjadi bagian dari sistem pembiayaan kredit. 


\section{KESIMPULAN DANREKOMENDASI}

\section{A. Kesimpulan}

1. Dalam skema kredit perlu dibedakan kondisi sosial ekonomi wilayah khususnya antara petani di P. Jawa dan Luar Jawa. Untuk petani hutan di P. Jawa kredit agar difokuskan pada aneka usaha kehutanan yang arahnya pemanfaatan lahan petani secara optimal. Sedangkan di Luar Jawa difokuskan pada kayu mengingat masih luasnya lahan milik petani. Oleh karena itu pola atau paket kredit perlu dibuat lebih bervariasi.

2 Kriteria Mitra Kelompok Petani harus lebih jelas untuk menjamin pemanfaatan kredit maupun penjaminan dan pengembaliannya. Oleh karena itu sasaran penerima kredit sebaiknya ditujukan kepada industri pengguna kayu yang telah ada.

3. Kepentingan petani dalam pemanfaatan kredit dan manfaat hasilnya sebaiknya difokuskan pada terms of contract antara Perusahaan mitra dengan Klpk petani berdasarkan azas saling menguntungkan.

4. Untuk keperluan pendanaan perkreditan perlu dibentuk badan khusus di DepHut yang terlepas (independen) dari birokrasi lainnya.

5. Hutan rakyat perlu dikembangkan sebagai sistem agribisnis atau agro-forest bisnis untuk memperluas penerimaan dari perbankan dan lembaga keuangan lainnya. Dalam sistem ini unit manajemen usaha dan skala ekonomi, komoditas, serta keterkaitan dengan pasar (industri) perlu lebih diperjelas.

6. Peranan bank disesuaikan dengan tujuan program pemberian kredit. Untuk program yang semata-mata tidak sepenuhnya bertujuan komersial seperti untuk konservasi maka bank lebih sesuai untuk chanelling, sedangkan untuk program yang berorientasi ekonomi dengan perhitungan kelayakan finansial maka bank dapat berperan sebagai executing agent.

7. Sumber pembiayaan /pendanaan bagi perkreditan sebaiknya campuran dari DR, bank nasional, serta pendanaan dari Luar Negeri. Untuk pendanaan LN pemerintah sebaiknya menarik dana dari OPEC funds yang berbunga cukup rendah, dan sumber dana yang berasal dari penjualan karbon. Dengan demikian tingkat suku bunga kredit yang ditawarkan kepada petani dapat ditekan.

\section{B. Rekomendasi}

1. Untuk pembuatan terms of contract antara perusahaan mitra kelompok tani hutan dan implementasinya perlu dilakukan pendampingan oleh instansi pemerintah yang berkompeten atau oleh LSM.

2. Untuk Perubahan hutan rakyat tradisional menjadi suatu sistem agro-forest binis diperlukan diperlukan peningkatan kemampuan SDM, memperkuat kelembagaan yang ada dan mengurangi hambatan-hambatan yang terjadi. 


\section{DAFTAR PUSTAKA}

Arifin,T.U. Hassan. 2004. Pendanaan Pembangunan Kehutanan Secara Berkesinambungan. Makalah Utama. Seminar Pembangunan Hutan Tanaman.Bogor, 6 Oktober 2004.Puslitbang Sosial Budaya dan Ekonomi Kehutanan.Bogor.

Costa, P.M., J. Salmi, M.Simula, C. Wilson.1999.Financial Mechanisms for Sustainable Forestry.UNDP/SEED.Helsinki-Oxford.

Darusman,D. 2004. Mengapa Hutan Tanaman Industri Kurang Berkembang. Makalah Tanggapan.Seminar Pembangunan Hutan Tanaman.Bogor, 6 Oktober 2004.Puslitbang Sosial Budaya dan Ekonomi Kehutanan. Bogor.

Forindo Bangun Konsultan.1999.Evaluasi Pelaksanaan Kredit Usaha Hutan Rakyat dan Usahatani Persuteraan Alam. Departemen Kehutanan dan Perkebunan. Jakarta.

Hardjanto. 2003. Keragaan dan Pengembangan Usaha Kayu Rakyat di Pulau Jawa.Program Pasca Sarjana IPB. Bogor.

Irawanti, S., Sylviani,E.Syahadat, L.Indracahya. 2000. Analisis Efektivitas Skim Kredit Usaha Tani Konservasi dan Hutan Rakyat.Laporan Penelitian. Pusat Penelitian Sosial Ekonomi Kehutanan dan Perkebunan. Bogor.

Munandar, Imam. 2004. Manajer Pemasaran BNI Jakarta.Konsultasi Publik Analisis Kebijakan "Optimalisasi Skim Pendanaan Rehabilitasi Hutan dan Lahan". Bogor, 16 Desember 2004.

Opecfunds. 2004. Website www.opecfunds.org. Diakses pada tanggal 1 November 2004.

Sarono, S.2004. Direktur PT Xylo Pratama-Jakarta. Konsultasi Publik Analisis Kebijakan "Optimalisasi Skim Pendanaan Rehabilitasi Hutan dan Lahan", Bogor, 16 Desember 2004.

Riyadi, Sugeng. 2004. Pegawai BRI Jakarta.Konsultasi PublikAnalisis Kebijakan "Optimalisasi Skim Pendanaan Rehabilitasi Hutan dan Lahan", Bogor, 16 Desember 2004.

Sylviani dan S. Irawanti. 2000. Pola Pengembangan Hutan Rakyat Melalui Skim Kredit Hutan Rakyat dan Konservasi (Studi Kasus Sumatera Selatan). Info Sosial Ekonomi 1(1): 37-48.Puslit Sosial Ekonomi Kehutanan dan Perkebunan. Bogor.

Wahyudi, A. dan S.Wulandari. 2000. Analisis Sistem Perkreditan Usahatani Tebu.Jurnal Sosial Ekonomi 1(1): 85-99. Puslit Sosial Ekonomi Kehutanan dan Perkebunan. Bogor. 
LAMPIRAN. Bagan Alir Pengajuan dan Penyaluran Kredit Usaha Hutan Rakyat

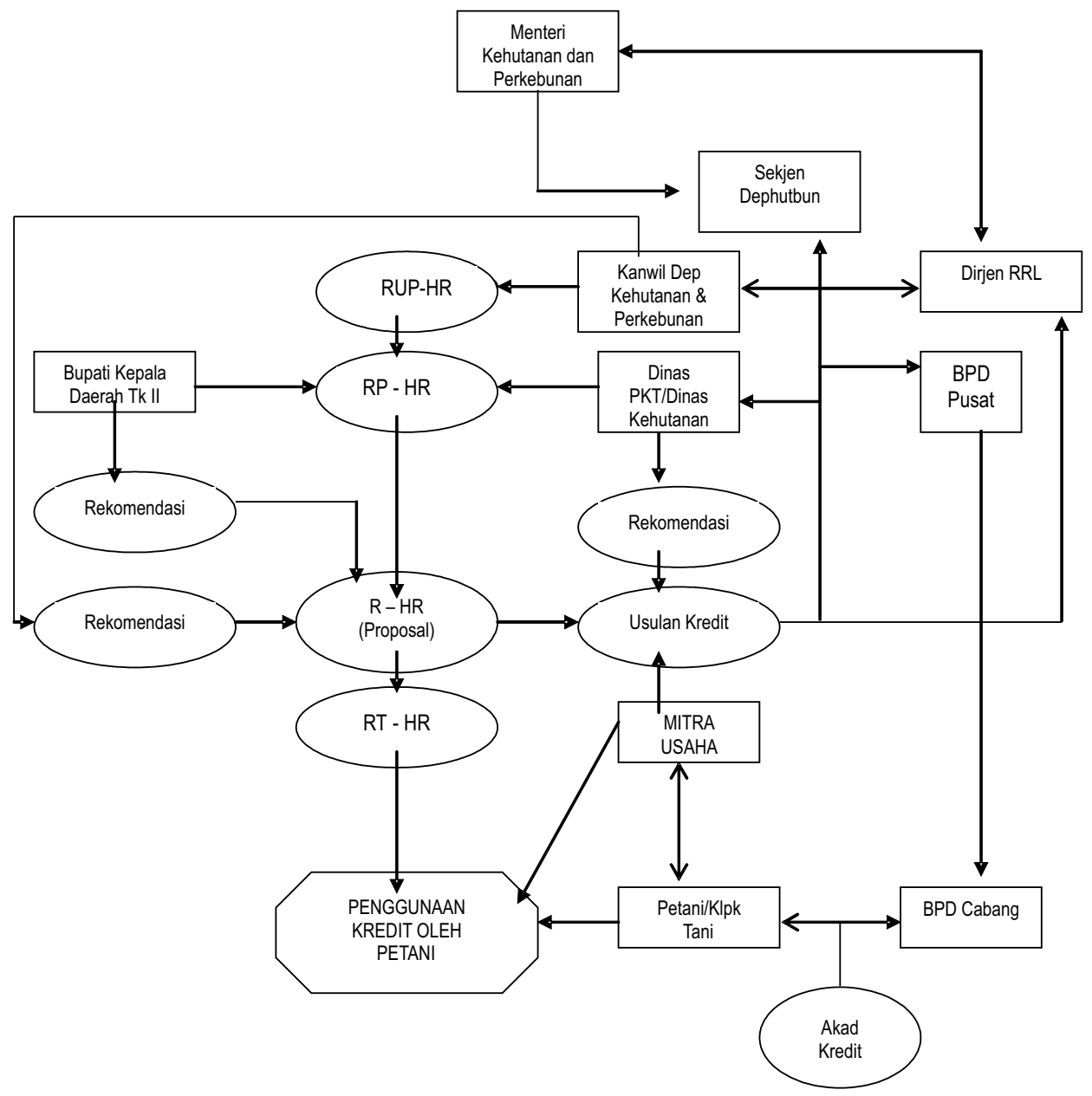

